\title{
KEKUATAN TRIPLE HELIX DALAM USAHA PENINGKATAN KUALITAS PRODUKSI PERAJIN BAMBU DI KERTAYASA, MANDIRAJA, BANJARNEGARA, JAWA TENGAH
}

Retno Purwandari ${ }^{1}$ (usagieno@yahoo.com, Jurusan Kriya Fakultas Seni Rupa Institut Seni Indonesia Yogyakarta)

\begin{abstract}
Triple helix is the power of a synergy between academics, business people, and the government. These powers seeded as one way to maximize have been potential fields regions throughout Indonesia. One program that describes force triple helix is Program Kemitraan Masyarakat (PKM) of ristekdikti. PKM have done 2017 from the volunteers of Art Institute Indonesia Yogyakarta is "IbM Usaha Kerajinan Bambu "D'Bantar Bamboo Craft" dan "Ali's Bamboo Craft" di Desa Kertayasa, Kecamatan Mandiraja, Kabupaten Banjarnegara". PKM done it has various program aimed to improve the quality and the production of bamboo. This program has been implemented because bamboo in this village is one of the pillars of the government in improving the welfare of the village community Kertayasa, Banjarnegara. These programs are to be given priority to: a). The development of design product, b). Diversified products, c). The procurement of production machine, and d). Provisions for management.Training and participation partner who directly involved is right methods and profitable for the government and partner, as by means of like this partner felt responsible for himself and the government in managing local potential. Hence, as broad outline focused training to: a). Training design making, b). Training deversified products, c). Task of procuring, and d). Training in management. A whole these activites having the main target, among others in the form of: expertise make a design, products craft bamboo, efficient technology to, and energy skilled. Thus, problems partner would gradually handled well.
\end{abstract}

Keywords: Triple Helix, PKM (Program Kemitraan Masyarakat), bamboo craft, Banjarnegara

\section{ABSTRAK}

Triple Helix merupakan kekuatan sinergi antara akademisi, pebisnis, dan pemerintah. Kekuatan ini sangat diunggulkan sebagai salah satu cara untuk memaksimalkan potensi-potensi daerah di seluruh Indonesia. Salah satu program yang menggambarkan kekuatan triple helix ini ialah Program Kemitraan Masyarakat (PKM) dari Ristekdikti. PKM yang telah terlaksana tahun 2017 ini dari para pengabdi ISI Yogyakarta ialah "IbM Usaha Kerajinan Bambu "D'Bantar Bamboo Craft" dan "Ali's Bamboo Craft" di Desa Kertayasa, Kecamatan Mandiraja, Kabupaten Banjarnegara". PKM yang telah terlaksana ini melakukan berbagai program kegiatan yang bertujuan meningkatkan kualitas dan percepatan produksi bambu. Program ini dilaksanakan karena bambu di desa ini merupakan salah satu pilar pemerintah dalam meningkatkan kesejahteraan masyarakat Desa Kertayasa, Kabupaten Banjarnegara. Program-program tersebut diprioritaskan pada: a). Pengembangan Desain Produk, b). Diversifikasi Produk, c). Pengadaan Mesin Produksi, serta d). Pembekalan Manajemen.Pelatihan dan Partisipasi mitra yang terlibat langsung merupakan metode yang tepat dan menguntungkan bagi pemerintah dan mitra, karena dengan cara seperti ini mitra merasa bertanggung jawab terhadap dirinya sendiri dan pemerintah dalam mengelola potensi lokal. Pelatihan difokuskan pada: a). Pelatihan Pembuatan Desain, b). Pelatihan Diversifikasi Produk, c). Pengadaan Alat, dan d). Pelatihan Manajemen. Keseluruhan kegiatan tersebut memiliki target utama, antara lain berupa: keahlian membuat desain, produk kerajinan bambu, teknologi tepat 
guna, dan tenaga terampil. Dengan demikian, persoalan mitra secara perlahan akan teratasi dengan baik.

Kata Kunci : Triple Helix, PKM (Program Kemitraan Masyarakat)), kerajinan bambu, Banjarnegara

\section{PENDAHULUAN}

Salah satu penopang perekonomian Indonesia saat ini ialah bidang kerajinan. Hal ini sejalan dengan kekayaan alamnya yang melimpah ruah, seperti berbagai macam tumbuhan yang bisa hidup subur di tanah Nusantara ini. Segala sumber daya alam telah diolah dan diramu dengan balutan tradisi dan budaya Indonesia, sehingga mampu menghasilkan keanekaragaman budaya berupa benda-benda sarat kultural dan estetik. Sebagai contoh, kayu merupakan sumber daya alam Indonesia yang banyak ditemukan tersebar dari Sabang sampai Merauke. Berjenis-jenis kayu dapat kita temukan di negeri ini. Bermediakan kayu ini, Jepara mampu menjadi kota legendaris yang terkenal akan kehalusan ukirannya, diaplikasikan ke dalam benda-benda fungsional, seperti meja, kursi, almari, dan tempat tidur. Jepara hanya salah satu contohnya, masih banyak kota-kota lain yang masyarakatnya menjadi pelaku-pelaku UMKM (Usaha Mikro Kecil dan Menengah).

Menurut Putro, Pemimpin Wilayah BRI, Yogyakarta dan sebagian wilayah Jawa Tengah merupakan gudangnya UMKM, mengingat UMKM merupakan pilar kekuatan potensial sebagai peran strategis dalam perekonomian nasional (2017: 10). Berbagai jenis usaha dan produk dapat ditemukan melalui tangan-tangan UMKM. Namun demikian, jika UMKM tidak digarap dengan maksimal, potensi tersebut bisa terlewatkan begitu saja. Oleh karena itu, para pelaku usaha di sektor ini perlu mendapat perhatian, bimbingan, dan dukungan dari berbagai pihak. Pihak-pihak yang berperan penting dalam sektor perdagangan, perekonomian, ataupun perindustrian disebutlah dengan Triple Helix, yakni sinergi kekuatan antara akademisi, pebisnis, dan pemerintah.
Kekuatan triple helix ini bisa dilihat dari beberapa program yang ditawarkan oleh Ristekdikti, baik program penelitian maupun pengabdian. "Undang-undang Guru dan Dosen (UU No. 14 Tahun 2005) mengamanatkan bahwa dosen adalah pendidik profesional dan ilmuwan dengan tugas utama mentransformasikan, mengembangkan, dan menyebarluaskan ilmu pengetahuan, teknologi, dan seni melalui pendidikan, penelitian, dan pengabdian kepada masyarakat (Radjasa melalui Direktorat Riset dan Pengabdian kepada Masyarakat, 2017: 3). Hal ini mengingatkan bahwa tugas dosen di perguruan tinggi sebagai salah satu penopang pilar pendidikan tinggi di Indonesia tidak hanya terbatas sekedar memberikan pengajaran di kelas. Dosen harus bisa memenuhi tugas Tri Dharma Perguruan tinggi, yakni meliputi Pengajaran, Penelitian, dan Pengabdian. Untuk mendukung tugas Tri Dharma Perguruan Tinggi inilah, Ristekdikti menawarkan program penelitian dan pengabdian, yang salah satunya tersebutlah Program Ipteks bagi Masyarakat (IbM) yang sekarang dikenal dengan Program Kemitraan Masyarakat (PKM).

Direktorat Riset dan Pengabdian kepada Masyarakat (DRPM) Ditjen Penguatan Risbang Kemenristekdikti mencoba menerapkan paradigma baru dalam kegiatan pengabdian kepada masyarakat yang bersifat problem solving, komprehensif, bermakna, tuntas, dan berkelanjutan (sustainable) dengan sasaran yang tidak tunggal. Hal inilah yang menjadi alasan dikembangkannya Program Kemitraan Masyarakat (PKM) (Direktorat Riset dan Pengabdian kepada Masyarakat, 2017: 304). Salah satu program yang telah berjalan selama tahun 2017 ialah PKM yang dilaksanakan di Kertayasa, 
Mandiraja, Banjarnegara, Jawa Tengah dengan judul "IbM Usaha Kerajinan Bambu "D'Bantar Bamboo Craft" dan "Ali's Bamboo Craft" di Desa Kertayasa, Kecamatan Mandiraja, Kabupaten Banjarnegara, Jawa Tengah" yang diketuai oleh Retno Purwandari, M.A. dengan anggota Ahmad Zaenuri, M.Sn. Judul kegiatan ini masih menggunakan istilah IbM, sesuai dengan usulan yang diajukan tahun 2016 .

Melalui artikel ini akan dipaparkan, seperti apa bentuk kerja sama dengan mengunggulkan kekuatan triple helix antara perguruan tinggi, ISI Yogyakarta; pemerintah, Bapeda dan Disperindag Banjarnegara; serta mitra bisnis, perajin bambu di Banjarnegara.

\section{Dukungan Pemerintah Banjarnegara dalam Pelaksanaan Program Kemitraan Masyarakat (PKM)}

PKM untuk perajin bambu di Banjarnegara bisa terlaksana dengan cukup baik karena salah satu alasannya mendapat dukungan penuh dari pemerintah Banjarnegara. Bappeda (Badan Perencanaan Pembangunan Daerah) Banjarnegara sebagai lembaga teknis daerah di bidang penelitian dan perencanaan pembangunan daerah yang dipimpin oleh seorang kepala badan yang berada di bawah dan bertanggung jawab kepada gubernur/bupati/wali kota melalui sekretaris daerah berperan penting mulai dari memberikan izin, kesempatan untuk bekerja sama dengan pihak perguruan tinggi, dalam hal ini ISI Yogyakarta melalui program pengabdian Ristekdikti. Badan ini mempunyai tugas pokok membantu Gubernur/Bupati/Wali kota dalam penyelenggaraan Pemerintahan Daerah di bidang penelitian dan perencanaan pembangunan daerah.

Beberapa fungsi kerja Bappeda dirasa cukup penting, sehingga menjadikan salah satu lembaga yang didatangi penulis dan tim untuk diminta bukti hitam di atas putih supaya memberikan kesanggupan kerja sama dalam program PKM. Fungsi-fungsi tersebut di antaranya: menyelenggarakan penelitian di bidang pemerintahan; menyusun pola dasar pembangunan daerah; menyusun REPELITA daerah; menyusun program tahunan daerah; dan melaksanakan kerja sama penelitian dan perencanaan pembangunan daerah dengan lembaga perguruan tinggi dan lembaga lain baik pemerintah maupun swasta. Setelah melakukan pembicaraan mengenai PKM yang akan dilaksanakan, Bappeda menyetujui untuk ikut memberikan dukungan penuh untuk pelaksanaan PKM, yang kemudian mereka susun untuk rencana di tahun yang sama dengan pelaksanaan program sesuai proposal PKM-nya. Surat kesediaan kerja sama yang dikeluarkan Bappeda Banjarnegara menjadi bukti atas dukungan pemerintah Banjarnegara untuk melakukan kerja sama dengan perguruan tinggi dalam rangka peningkatan sumber daya masyarakat.

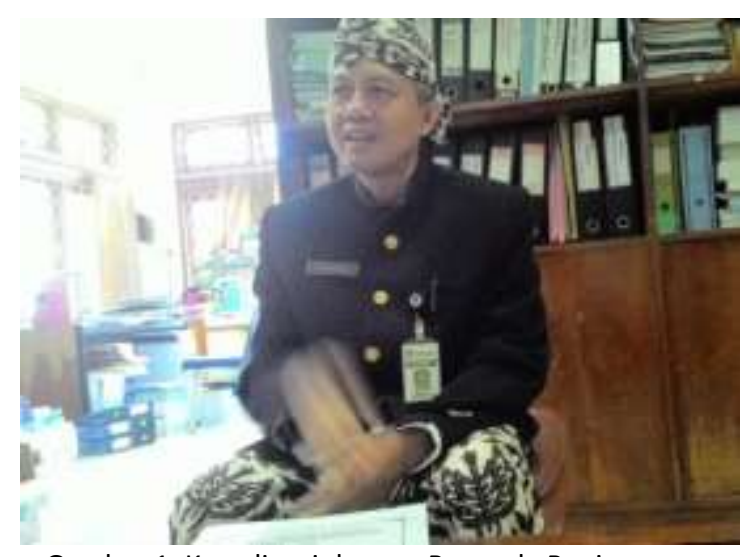

Gambar 1. Koordinasi dengan Bappeda Banjarnegara (Sumber: Dokumentasi Penulis, Diambil 2016)

Dalam setiap perjalanannya, pemerintah Banjarnegara selalu siap sedia mendampingi pelaksanaan program melalui tangan Disperindag (Dinas Perindustrian dan Perdagangan) Banjarnegara. Beberapa kegiatan selama berjalannya program, pihak Disperindag Banjarnegara selalu ikut serta mendampingi, seperti pertemuan dengan para perajin, pelatihan-pelatihan, dan penyerahan alat atau mesin produksi pun diterima oleh pihak Disperindag untuk dipasrahkan ke para perajin. Bahkan pelatihan manajemen pun mengambil tempat di Kantor Disperindag Banjarnegara. 


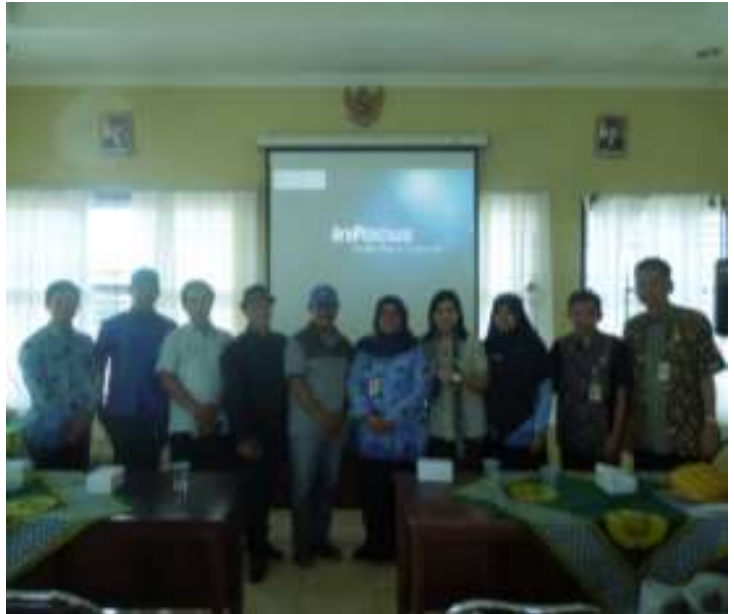

Gambar 2. Koordinasi Pelaksanaan PKM antara Pengabdi dengan Disperindag Banjarnegara

(Sumber: Dokumentasi Penulis, Diambil 2017)

\section{D'Bantar Bamboo Craft dan Ali's Bamboo Craft sebagai Mitra PKM}

Kedua UKM yang menjadi mitra memiliki kondisi sumber daya manusia yang sama. UKM I "D'Bantar Bamboo Craft" memulai usaha membuat anyaman bambu sejak tahun 1995, namun kegiatan menganyam sudah ditekuni oleh masyarakat semenjak sebelum 1945 hingga kini dengan tenaga kerja berjumlah 7 orang perajin. Ratarata mereka belum memiliki keahlian yang mumpuni, seperti inovasi menganyam bambu dikarenakan sebagian besar perajin adalah penggarap tegalan. Disela-sela waktu luang itulah, mereka membuat produk anyaman. Begitu pula UKM II, "Ali's Bamboo Craft" memulai usaha membuat anyaman bamboo sejak tahun 1985 namun ditekuni oleh masyarakat semenjak sebelum 1945 hingga kini dengan tenaga kerja berjumlah 20 orang perajin. Rata-rata mereka belum memiliki keahlian yang mumpuni, seperti inovasi menganyam karena kegiatan menganyam bambu hanyalah pekerjaan sampingan selain bertani.

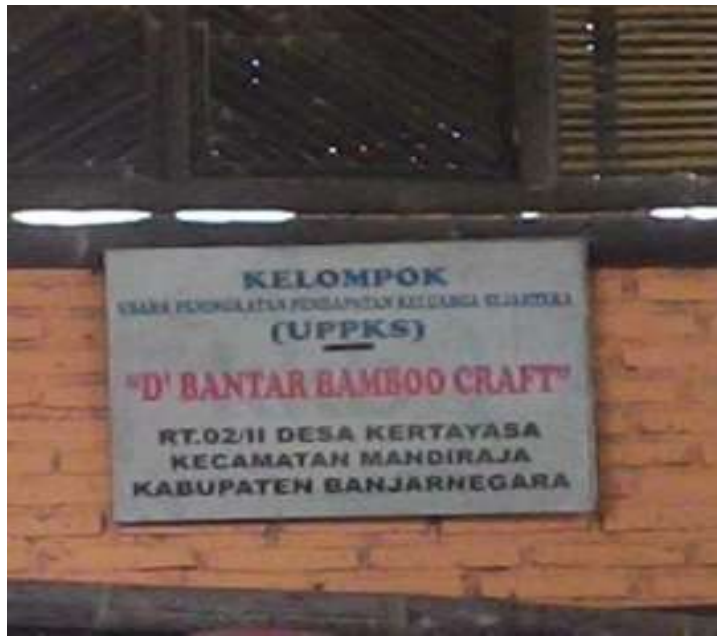

Gambar 3. Papan Nama Kelompok Kerajinan (Sumber: Dokumentasi Penulis, Diambil 2017)

UKM I dan UKM II memperoleh bahan baku bambu dari tanaman-tanaman bambu yang tumbuh di sekitar rumah mereka masing-masing. Harga bambu berkisar Rp. 15.000,- hingga Rp. 40.000,- per batang. UKM I biasa menghabiskan 150 batang per bulan, sedang UKM II menghabiskan 120 batang per bulan. Meskipun demikian, persediaan bahan bambu masih mencukupi. Artinya, dari sisi bahan baku tidak menjadi masalah. Mereka mengawali pembuatan produk bambu karena melihat ada potensi alam yang bisa dikembangkan menjadi sentra industri atau wirausaha mandiri, artinya potensi seperti itu bisa dikembangkan seperti wilayah kerajinan bambu di daerah Tasikmalaya, Cirebon, Magelang, ataupun daerah lainnya.

UKM I "D'Bantar Bamboo Craft" sejak tahun 1995 fokus pada produk anyam untuk keperluan rumah tangga dan aksesoris rumah, seperti tempat nasi, tempat jajan, tempat buah, tempat tisu, tudung saji, lampu, dan kerai. Harga jual produk anyam berkisar Rp.12.000,- sampai dengan Rp.300.000,- per unit. UKM II "Ali's Bamboo Craft" sejak awal menekuni peralatan rumah tangga, seperti tudung saji dan tampah. Harga berkisar antara Rp.20.000,- hingga Rp.300.000,-. Meskipun jenis produk serupa sudah banyak di beberapa daerah, konsumen tetap mencari produk buatan UKM "D'Bantar Bamboo Craft" dan UKM "Ali's Bamboo Craft". 


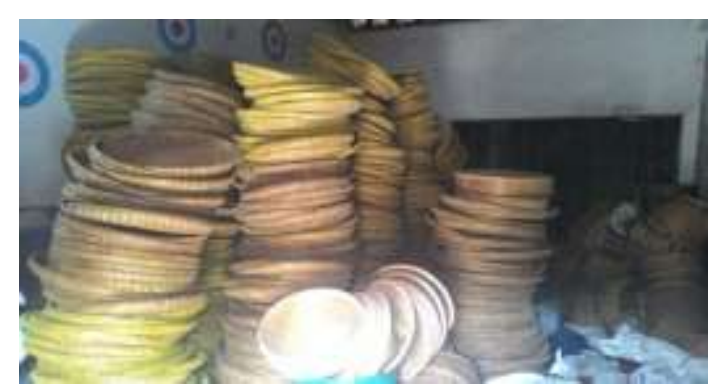

Gambar 4. Produk-Produk yang Biasa Dibuat Mitra PKM (Sumber: Dokumentasi Penulis, Diambil 2017)

Keterbatasan alat dan teknologi merupakan salah satu penyebab kedua UKM ini tidak bisa dikembangkan secara maksimal. Alat-alat seperti mesin pemotong bambu, Hollmortiser, pisau raut, alat finishing mutlak dimiliki jika ingin melakukan diversifikasi produk. Produk-produk UKM I "D'Bantar Bamboo Craft" sebagian besar sudah dikerjakan secara maksimal, sehingga produknya halus dan presisi dari segi ukurannya, serta lebih beragam. Sedangkan UKM II "Ali's Bamboo Craft" tidak memiliki alat secara lengkap, kebanyakan produknya dikerjakan dengan alat manual dan apa adanya, sehingga produksinya pun lamban, serta kurang beragam.

Produk kerajinan bambu UKM I dan UKM II di Desa Kertayasa, Banjarnegara masih memiliki pasar lokal di wilayah Banjarnegara dan sekitarnya, sedangkan pemasaran antarpulau sudah dilakukan meskipun masih sangat terbatas. Hal ini disebabkan karena kurangnya sarana dan alat promosi ke luar daerah, seperti pameran, katalog, leaflet, dan media on line. Jika ingin memiliki pasar dengan jangkauan lebih luas: antarpropinsi, antarpulau, nasional, maupun international, pameran, promosi secara off line dan on line harus dilakukan. Meskipun promosi merupakan hal penting, desain produk adalah salah satu faktor yang harus dipertimbangkan, sebab desain merupakan salah satu pilar dari nilai produk yang bisa menciptakan pasar secara baik dan luas. Kedua UKM tersebut belum bisa membuat desain dengan unsur kebaruan atau produk kebaruan yang disebut sebagai "Tren Desain". Hal ini bisa dikatakan sebagai kelemahan dari kedua UKM tersebut. Oleh karena itu, pada program ini diadakan pelatihan diversifikasi produk melalui pengembangan desain yang mengarah kepada tren desain.

Persoalan manajemen mungkin belum menjadi hal penting bagi kedua UKM kerajinan bambu di Kertayasa, karena terlihat selama ini belum memiliki pembukuan yang baik. Mereka belum terbiasa mencatat keluar masuk keuangan, menata tempat kerja, mengatur tenaga kerja, mengendalikan produksi, dan lain-lain. Hal ini disebabkan belum memiliki pengetahuan tentang manajemen. Namun demikian, sebenarnya mereka memahami bahwa usahanya tidak bisa berkembang karena tidak dikelola secara baik. Keterbatasan-keterbatasan tersebut sudah diupayakan melalui program-program pelatihan dan pendidikan oleh pemerintah setempat, seperti Disperindag Banjarnegara dengan melibatkan Perguruan Tinggi terdekat, seperti UNSUD, UNNES, dan ISI Yogyakarta, tetapi upaya itu sampai saat ini belum bisa mengatasi persoalan secara menyeluruh.

\section{Permasalahan Mitra dan Solusi yang Dilakukan dalam PKM}

Permasalahan-permasalahan kedua UKM mitra yang sifatnya mendesak saat ini antara lain: terbatasnya desain produk yang kurang marketable, belum tersedianya teknologi tepat guna, dan belum tersedianya alat pelengkap yang memadai, serta belum tertatanya manajemen pemasaran dan manajemen produksi. Untuk itu, permasalahan yang diupayakan ditangani adalah: Pengembangan desain bambu; Diversifikasi produk; Pengadaan mesin produksi; dan Penataan manajemen pemasaran dan kualitas produk.

Hal tersebut sejalan dengan yang diungkapkan Prasetyo (2007: 167), kinerja pasar seperti produktivitas, efisiensi, produksi, pendapatan, dan keuntungan dipengaruhi oleh perilaku pasar input: strategi kualitas, desain produk, pembelian, inovasi; dan perilaku pasar output: strategi harga, penjualan, produk, dan promosi. Aspek-aspek disebut di atas tidak semua akan kita sentuh dalam program ini, hanya beberapa saja mengingat keterbatasan waktu dan jarak. Halhal yang akan kita singgung meliputi aspek 
kualitas, desain produk, inovasi, produk, dan promosi melalui kegiatan pelatihan.

\section{Kegiatan-Kegiatan yang Dilakukan sebagai Solusi Permasalahan Mitra \\ Pelatihan dan Partisipasi yang} melibatkan langsung masyarakat merupakan metode yang tepat dan menguntungkan bagi pemerintah dan masyarakat, karena dengan cara demikian masyarakat merasa memiliki tanggung jawab bersama pemerintah dalam mengelola potensi daerah. Sektor kerajinan bambu saat ini merupakan aset baru bagi perekonomian masyarakat Banjarnegara, namun demikian masih banyak kekurangankekurangan yang perlu ditingkatkan secara serius, sebab belum dikelola dengan benar dan maksimal. Permasalah Mitra yang sifatnya mendesak saat ini adalah: pengembangan desain produk dan alat bantu atau mesin produksi. Guna mengatasi persoalan tersebut PKM telah melakukan serangkaian kegiatan sebagai berikut:

\section{Survei dan Koordinasi dengan UKM dan Disperindag}

Kegiatan ini merupakan kegiatan sosialisasi mengenai program yang akan dilaksanakan disesuaikan dengan kondisi, serta sesuai dengan kesepakatan antara mitra, yakni perajin, pemerintah, dan pengabdi. Pada kegiatan ini pihak pemerintah Banjarnegara memberikan dukungan yang luar biasa. Mereka menyambut baik dan siap untuk membantu fasilitas yang dibutuhkan selama melakukan kegiatan. Pihak mitra sendiri sangat antusias untuk menunggu kegiatan-kegiatan selanjutnya yang telah disepakati.

\section{Pelatihan Pengembangan Desain}

Menurut Stanton, desain produk merupakan salah satu aspek pembentuk citra produk. Yang makin disadari oleh suatu perusahaan ialah pentingnya nilai pemasaran dari desain produk terutama desain penampilannya, menyangkut warna dan kualitas produk (Ilmaya, 2011: 44). Untuk itu, memang sangat perlu dilakukan pelatihan desain produk bagi para perajin.
Materi pelatihan adalah menyiapkan desain-desain yang sesuai dengan permintaan pasar, juga menyiapkan desain sesuai dengan tren desain tahun-tahun berikutnya. Sachari mengungkapkan beberapa pendapat ahli mengenai pentingnya desain, salah satunya ialah pendapat Jones (1970) bahwa desain adalah tindakan dan inisiatif untuk mengubah karya manusia (2000: 12).

Pada mulanya, pelatihan ini direncanakan untuk mengajarkan membuat desain dengan menggunakan komputer, akan tetapi ternyata kondisi masyarakat peserta pelatihan banyak yang tidak bisa mengoperasikan komputer. Selain itu pula, ternyata mereka belum mampu bagaimana cara merancang produk dengan membuat desain terlebih dahulu. Oleh karena itu, pelatihan kali ini difokuskan dengan melatih menggambar desain di atas kertas dengan menggunakan pensil gambar. Peserta pelatihan cukup antusias, sehingga mampu menghasilkan beberapa gambar desain produk dengan variasinya. Desain yang dihasilkan berupa desain wadah, bisa untuk tempat buah atau yang lainnya; aksesoris, seperti lampu duduk, lampu tempel; hiasan, seperti cermin dinding; peralatan rumah tangga, seperti tempat sendok, tatakan; dan vas.

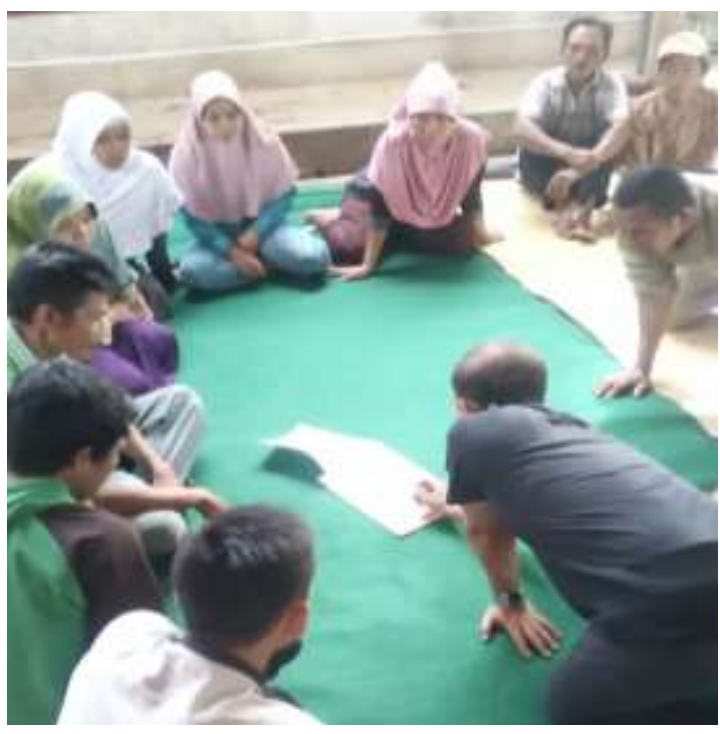

Gambar 5. Pelatihan Menggambar Desain

(Sumber: Dokumentasi Penulis, Diambil 2017)

Gambar desain produk yang telah dihasilkan menunjukkan bahwa para perajin 
mampu menyerap pelatihan tentang desain. Mereka mengerti bahwa sebelum membuat produk bisa diawali dengan membuat gambar desain, supaya terbiasa dengan budaya dokumentasi yang memiliki banya manfaat bagi perajin.

\section{Pengadaan Alat/Mesin Produksi}

Alat bantu produksi dibutuhkan untuk mempercepat produksi sekaligus juga supaya perajin lebih bisa mengkreasikan produknya. Mitra program PKM ini ternyata belum memiliki beberapa alat yang sekiranya bisa dipergunakan untuk mempermudah pekerjaannya. Untuk itu, melalui program ini, pengabdi melakukan pengadaan alat/mesin produksi, berupa: mesin gerinda, mesin bor tangan, mesin potong circle, dan Hollomortizer.

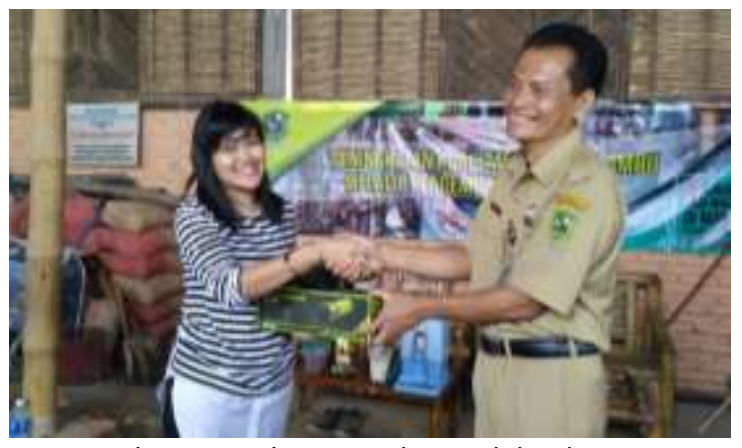

Gambar 5. Serah terima alat produksi diterima Disperindag.

(Sumber: Dokumentasi Penulis, Diambil 2017)

\section{Pelatihan Penggunaan Alat/Mesin Produksi}

Kegiatan ini tentu saja merupakan satu rangkaian kegiatan dengan pengadaan alat, karena alat yang diberikan belum begitu dipahami oleh para perajin. Untuk itu, perajin dan pelatih melakukan percobaan bersama untuk menggunakan alat tersebut. Kegiatan ini dimanfaatkan untuk pembuatan bahanbahan dari bambu yang sekiranya diperlukan dalam pembuatan produk sesuai dengan desain yang telah dibuat sebelumnya. Setelah perajin mampu mempergunakan alat tersebut, mereka melanjutkan percobaan mesin secara mandiri.

Respon perajin sangat antusias menerima mesin-mesin produksi tersebut, karena mereka langsung belajar bagaimana cara menggunakannya dan mempraktikkannya untuk digunakan dalam pembuatan produk berdasarkan desain yang telah dibuat dalam pelatihan sebelumnya. Menurut Suwarso, ketua D'Bantar Bamboo Craft, setelah dibantu dengan alat dan mesin produksi yang diberikan, proses produksi menjadi lebih cepat. Produk yang dihasilkan juga lebih dihalus dibandingkan sebelumnya. Untuk peningkatan jumlah produksi belum bisa disebutkan secara signifikan karena masih terkendala dengan belum mahirnya dalam mengoperasikan alat dan mesin produksi. Meskipun demikian, tetap bisa dikatakan bahwa jumlah produksi mengalami peningkatan sekitar 35\% setelah dibantu dengan alat dan mesin produksi (dalam percakapan Desember 2017).

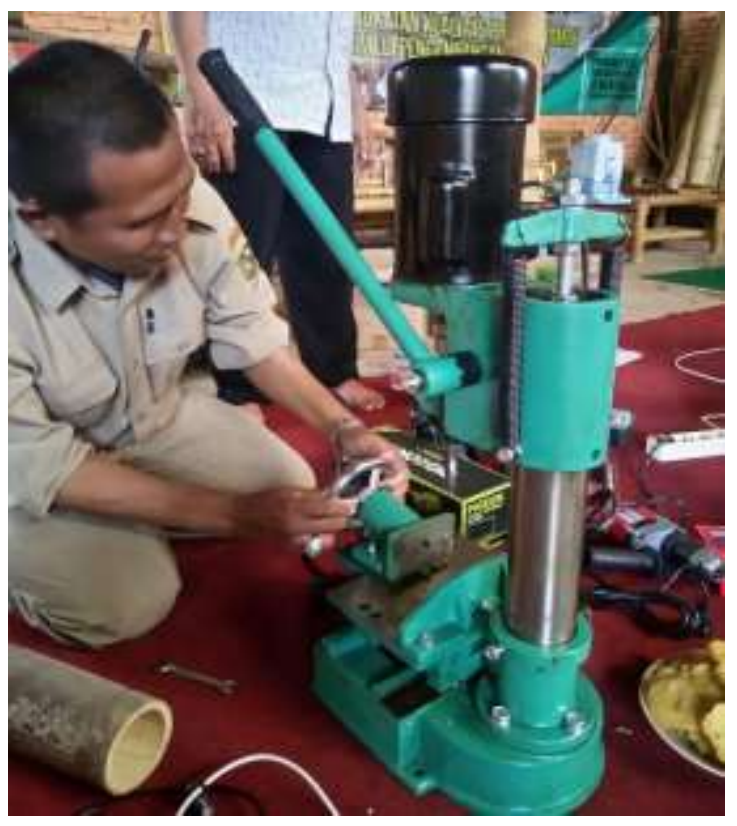

Gambar 6. Percobaan Hollomortizer

(Sumber: Dokumentasi Penulis, Diambil 2017)

\section{Pelatihan Pembuatan Produk}

Kegiatan ini merupakan kelanjutan dari kegiatan sebelumnya. Bermodal dari bahan-bahan yang telah disiapkan, perajin dipandu pelatih mulai mengerjakan pembuatan produk berdasarkan desain yang telah dibuat. Kegiatan ini dipandu mulai dari pembuatan produknya dari awal sampai tahap finishing. Setelah mampu, perajin bisa melanjutkan pekerjaannya secara mandiri. Produk-produk yang dihasilkan, yaitu: wadah, bisa untuk tempat buah; hiasan dinding, 
seperti cermin dinding; lampu, seperti lampu duduk, lampu tempel, lampu baca; peralatan rumah tangga, seperti tatakan, tempat sendok; dan vas.

Pelatihan membuat produk kebaruan, seperti keperluan rumah tangga dan aksesoris rumah. Kebaruan memiliki pengertian tidak harus berbeda dengan produk yang sudah ada, tetapi penambahan atau pembenahan motif, penambahan aksesoris, dan pengayaan fungsi produk sebagai salah satu bagian dari proses diversifikasi.

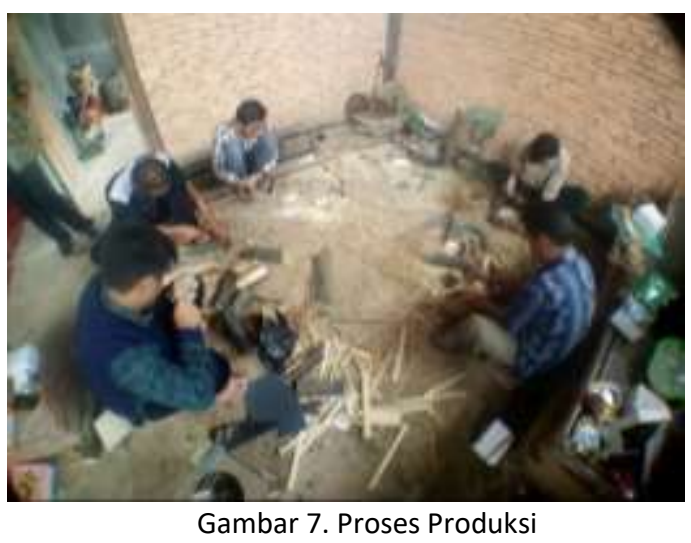

(Sumber: Dokumentasi Penulis, Diambil 2017)

Rangkaian kegiatan yang dimulai dari pelatihan desain, pelatihan penggunaan mesin produksi, dilanjutkan dengan pelatihan pembuatan produk kerajinan bambu, akhirnya dihasilkan beberapa produk bambu yang berbeda dari produk yang biasanya mereka buat. Produk-produk bambu yang dihasilkan ialah wadah, lampu duduk, lampu baca, lampu tempel, cermin dinding, vas, dan tatakan. Hasil yang dibuat cukup bagus dan membawa warna baru dari kebiasaan produksi yang mereka buat.

Menurut Suwarso, ketua D'Bantar Bamboo Craft, pelatihan desain produk dan diversifikasi produk ini membuka cakrawala para perajin. Mereka memiliki wawasan yang lebih luas, lebih terbuka untuk memainkan desain dan membuat produk, tidak hanya terpaku pada desain yang "itu-itu" saja (dalam percakapan Desember 2017).
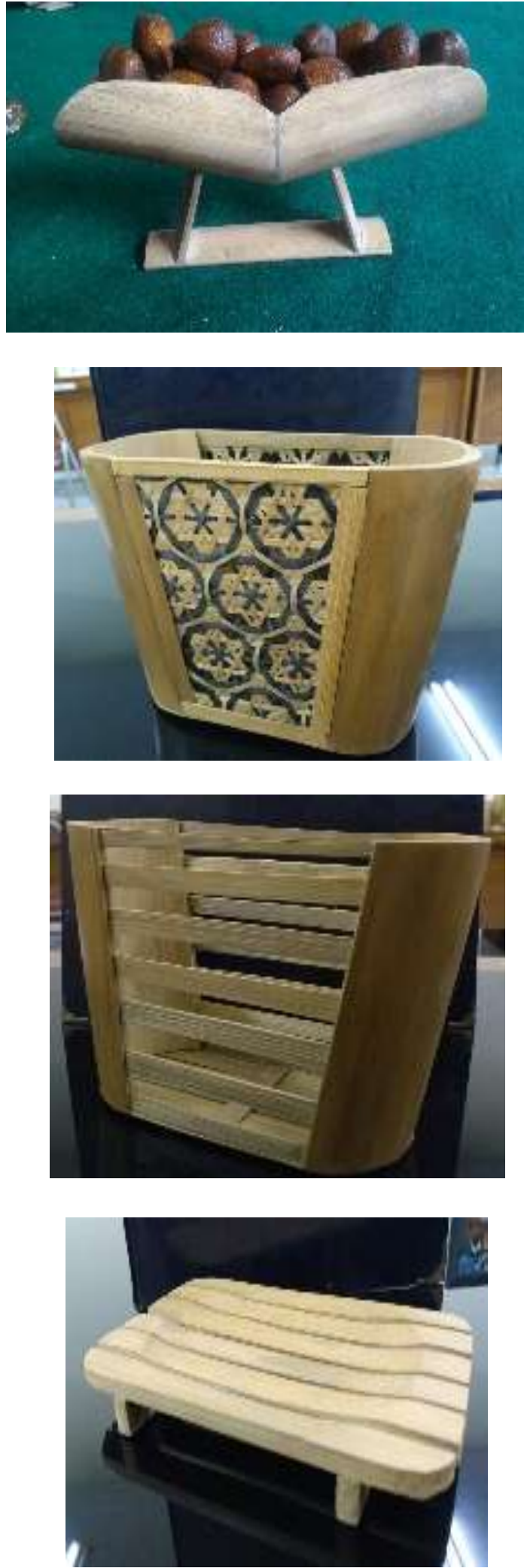

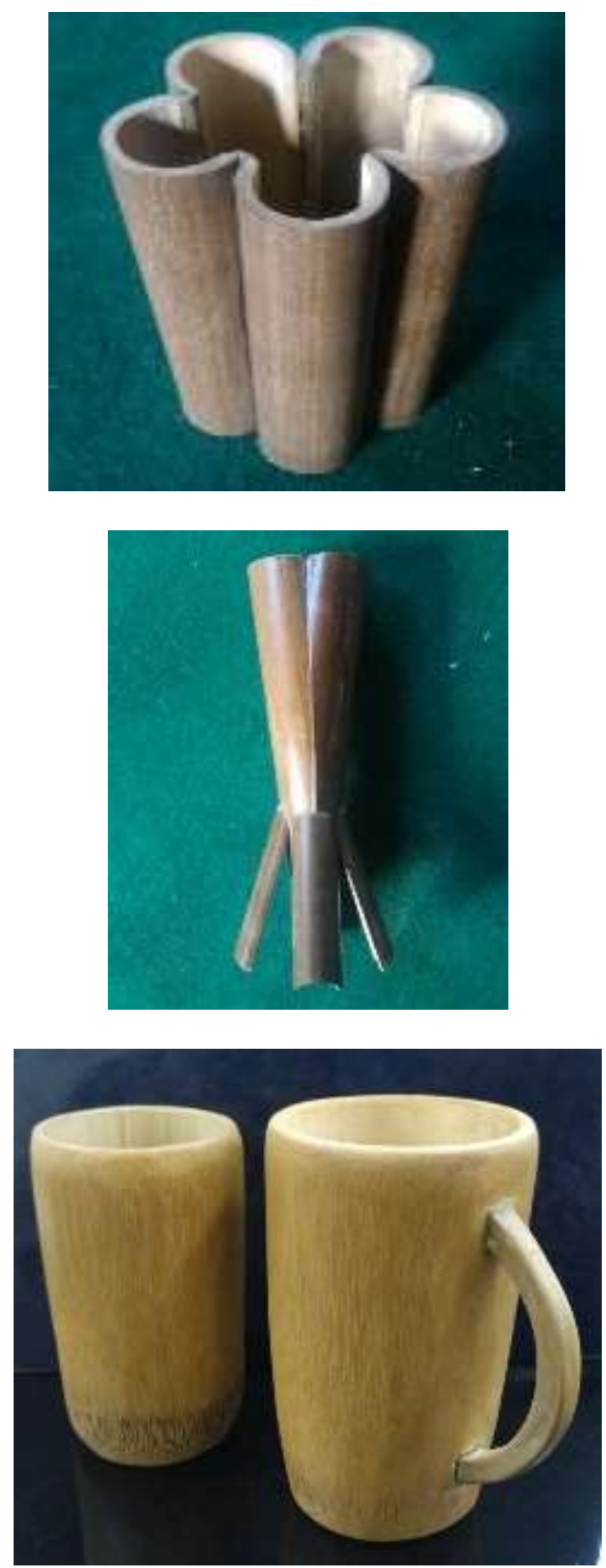

Gambar 8. Produk Bambu yang Dihasilkan (Sumber: Dokumentasi Penulis, 2017)

\section{Pelatihan Manajemen Pemasaran dan Peningkatan Kualitas Produk}

Kegiatan ini merupakan kegiatan terakhir dari rangkaian kegiatan PKM yang telah dilaksanakan. Kegiatan terakhir ini para perajin dilatih manajemen di dalam pemasaran. Perajin dikenalkan beberapa metode untuk memasarkan hasil-hasil produknya. Selain itu, perajin dilatih mengatur cara untuk meningkatkan kualitas produk. Untuk tujuan peningkatan kualitas, perajin meminta diadakan praktik untuk memperdalam kualitas produksi. Sebelumnya perajin diberi pencerahan mengenai desaindesain terkini yang efeknya para perajin kembali mampu mengkreasikan ide dengan cara mewujudkan produk baru dengan gaya desain modern.

Pelatihan manajemen peningkatan kualitas produk ditujukan kepada perajin untuk membekali pengetahuan dan keterampilan dalam berproduksi supaya tidak sekedar mengedepankan kuantitas tetapi juga kualitasnya. Hasil yang didapatkan setelah ada pengadaan alat dan mesin produksi yakni meningkatnya kuantitas produksi. Hal ini menunjukkan perubahan yang positif, karena alat dan mesin produksi tersebut mampu mempercepat proses produksi. Untuk itu, perlu dilengkapi dengan keterampilan peningkatan kualitasnya, yakni dengan memperdalam desain yang kekinian melalui pemanfaatan referensi-referensi pendukung yang bisa didapatkan secara daring. Dengan memperkaya referensi pendukung yang kekinian, perajin bisa mendesain satu produk yang multifungsi.

Finishing atau sentuhan terakhir untuk produk juga penting untuk lebih menarik konsumen. Hal ini difokuskan untuk memberikan sentuhan pada warna dan tekstur yang ditampilkan produk bambu tersebut.

\section{PENUTUP}

Berdasarkan kegiatan yang sudah dilaksanakan ini masih banyak kendala dan kekurangannya, seperti sulitnya mengumpulkan warga sekitar apabila pelatihan akan dilaksanakan. Kegiatan berproduksi hanya sebagai aktivitas sampingan yang tidak dikerjakan setiap saat, sehingga perajin tidak fokus dalam memajukan usahanya.

Melalui kegiatan yang berjalan selama kurang lebih delapan bulan ini, telah menghasilkan beberapa target, di antaranya desain-desain terbaru, mesin-mesin produksi, produk-produk bambu yang dibuat berdasarkan desain terbaru, dan keterampilan 
manajemen peningkatan kualitas produk. Ditambah pula kegiatan ini menghasilkan beberapa luaran berupa artikel ilmiah yang diterbitkan di jurnal ilmiah dan publikasi melalui media massa berupa surat kabar harian. Hasil-hasil yang telah tercapai diharapkan masih tetap berjalan untuk memudahkan dan melancarkan kegiatan para perajin. Selain itu pula, program ini memberikan banyak manfaat bagi pemerintah Banjarnegara.

Untuk meningkatkan kualitas alangkah baiknya antara perguruan tinggi, perajin, dan pemerintah daerah bekerja sama secara berkesinambungan mengatasi kendalakendala tersebut. Peran kampus bisa lebih meningkatkan permasalahan teknis desain yang lebih laku di pasaran, teknik produksi, dan manajeman. Sedangkan perajin lebih giat lagi meningkatkan kualitas produk dan menjalin mitra yang lebih maju untuk meningkatkan produksinya. Pemerintah daerah melalui program-programnya untuk memajukan perajin bisa memberikan kelonggaran fasilitas dalam berwirausaha.

\section{DAFTAR PUSTAKA}

Direktorat Riset dan Pengabdian kepada Masyarakat. 2017. Panduan Pelaksanaan Penelitian dan Pengabdian kepada Masyarakat di Perguruan Tinggi. Edisi XI 2017. Direktorat Riset dan Pengabdian kepada Masyarakat, Direktorat Jenderal Penguatan Riset dan Pengembangan, Kementerian Riset, Teknologi, dan Perguruan Tinggi Republik Indonesia.

Ilmaya, Fahma. 2011. "Analisis Pengaruh Interaksi Harga dan Desain Produk terhadap Keputusan Pembelian Batik di Eka Batik Semarang." Skripsi Fakultas Ekonomi Universitas Diponegoro Semarang.

Prasetyo, P. Eko. 2007. "Perilaku Perajin dalam Meningkatkan Kinerja Pasar." dalam Jurnal Ekonomi Pembangunan Vol. 8 No. 2 Desember 2007.

Putro, Andik Eko. 2017. "Angka Martabat UMKM.” dalam Surat Kabar Harian Kedaulatan Rakyat, Selasa Wage, 5 Desember 2017.
Sachari, Agus dan Yan Yan Sunarya. 2000. Pengantar Tinjauan Desain. Bandung: ITB (eBook). 